\title{
Un momento crucial para las Diputaciones provinciales
}

A veces, lo más efectivo para la consecución del objetivo propuesto es un corto artículo, unas cuantas líneas. Es por ello que esperamos utilizar muy poco espacio de esta magnífica publicación para expresar nuestra inquietud, nuestros temores en lo que se refiere a la real instauración y efectividad de la nueva institución de ia cooperación provincial a los servicios municipales y del nuevo arbitrio sobre la riqueza provincial. $Y$ nos permitimos expresar públicamente nuestros temores y nuestra inquietud por creer que con ello podemos contribuir a que está semilla de la ayuda provincial a las municipalidades-of recida por el legislador a las Diputaciones ricamente envuelta en el celofán del arbitrio sobre riqueza. provincial-fructifique debidamente en todas y cada una de las provincias.

\section{LA COOPERACIÓN PROVINCIAL}

La legislación actual atribuye a las Diputaciones la realización de la grandiosa Obra de la Cooperación Provincial a los Servicios. Municipales. Los tiempos cambian. La ayuda provincial a las municipalidades es hoy lạ razón de ser de las Diputaciones. Han' quedado postergadas las tradicionales razones existenciales basadas en los "Caminos vecinales", que pueden ser construídos perfectamente por las Jefaturas estatales de Obras Públicas, y en los “Establecimientos benéficos", que pueden quedar bajo la órbita estatal del. 
Régimen de Seguridad Social. Actualmente, la única razón de peso pro existencia de las Diputaciones provinciales es, pura y simplemente, la ayuda a los pueblos necesitados o indotados, en sus dos facetas: "Recurso especial de nivelación de Presupuestos municipales" y "Cooperación provincial». Esta última-salvo en algunos casos como, por ejemplo, Málaga o Alicante-es, desde luego, lo primordial, lo básico, lo fundamental.

iAy de las Diputaciones que no evolucionen! i Ay de las que no se lancen rápidamente, con todas sus fuerzas y dineros; por el: nuevo camino trazado por el legislador en la' última reforma del Régimen local! Si las Diputaciones se hubieran metido alegremente de lleno en la magnífica tarea de la ayuda a los pueblos, sin esperar la recaudación previa, esta tarea y la finalidad que ella implica serían hoy la mejor defensa contra la campaña surgida en relación a la inmediata o a la total efectividad del arbitrio sobre riqueza provincial. $Y$ vamos a tratar un poco de lo que ha ocurrido en torno a esta imposición.

\section{El ARBItrio SOBRE RIQUEZA PROVINCIAL}

No recordamos un caso igual al que se les ha planteado a las Diputaciones. Hay una protesta y oposición generales a que las Corporaciones provinciales perciban el total importe del arbitrio carrespondiente al ejercicio de 1954 . En una provincia se trata de conseguir que comience a cobrarse desde el $1 .^{\circ}$ de enero de 1955 ; en otra se quiere lograr que se cobre sólo uno de los dos semestres de 1954 ; en otra, en fin, se pretende obtener una rebaja en el tipo impositivo... Todo ello es muy desagradable para las Diputaciones, cuyos presupuestos fueron aprobados, teniendo en cuenta: ${ }^{b} a$ ), los ingresos que en 1954 obtendrían del mencionado arbitrio, y b), la supresión de ingresos procedentes de los recursos desaparecidos en el reformado cuadro impositivo de las Haciendas provinciales.

Unas Corporaciones de Derecho público no pueden hacer regalos al contribuyente, $y$. un regalo es no cobrarle las cantidades correspondientes al arbitrio en cuestión. Y ello redunda, además, en perjuicio de la economía provincial, de la debida prestación de 
las obligaciones y servicios provinciales y de la magna obra de la Cooperación provincial. Por otra parte, y dado que los Municipios tienen derecho pleno a percibir una participación del 10 por 100 en el rendimiento de dicho arbitrio provincial, es evidente que sin autorización de los Ayuntamientos de la circunscripción las Corporaciones provinciales no pueden pronunciarse sobre la materia.

He aquí la difícil situación por que atraviesan la mayoría de las Diputaciones. Quizá será preciso transigir en algo. Ello no será estrictamente jurídico, pero sí conveniente. Confiamos en que prevalecerá el interés común o general y que este crítico momento será superado para bien del Régimen local, de la vida provincial y de la municipal.

Luis Marqués Carbo

Secretario de $1 .{ }^{\text {a }}$ categoría de Administración local 